\title{
Fuel Consumption of Forwarders in Lowland Forests of Pedunculate Oak
}

\author{
Zdravko Pandur ${ }^{1 *}$, Marijan Šušnjar ${ }^{1}$, Marin Bačić ${ }^{1}$, Kruno Lepoglavec $^{1}$, Hrvoje Nevečerel $^{1}$, Andreja Đuka ${ }^{1}$
}

(1) University of Zagreb, Faculty of Forestry, Department of Forest Engineering, Svetošimunska 25, HR-10000 Zagreb, Croatia

* Correspondence: e-mail: zpandur@sumfak.hr
Citation: PANDUR Z, ŠUŠNJAR M, BAČIĆ $M$, LEPOGLAVEC K, NEVEČEREL H, ĐUKA A 2018 Fuel Consumption of Forwarders in Lowland Forests of Pedunculate Oak. South-east Eur for 9 (1): 73-80. DOI: https://doi.org/10.15177/seefor.18-07 Received: 5 Apr 2018; Revised: 29 May 2018; Accepted: 11 Jun 2018; Published online: 18 Jun 2018

\begin{abstract}
Background and Purpose: Fuel consumption in timber harvesting operations is significant for both economic and environmental reasons. In economic sense, one significant part of timber harvesting costs is reduced to fuel costs, and in environmental sense $80 \%$ to $95 \%$ of exhaust emissions and soot particles in forest machinery are in fact associated with fuel consumption.

Materials and Methods: The research object was a 6-wheel Valmet 840.2 forwarder and research was conducted in Forest Administration Vinkovci (lowland part of Croatia) during seeding felling in a stand of pedunculate oak and narrow-leafed ash. For the purpose of measuring fuel consumption on the researched forwarder a differential flow device was installed together with FMS (Fleet Management System) which was used for data transfer.

Results: Fuel consumption is expressed in six different ways concerning: cycle, extraction distance of $100 \mathrm{~m}$, time (hour), load mass (tons), gross load volume $\left(\mathrm{m}^{3}\right)$ and product of mass and transporting distance (tkm). Fuel consumption amounted to $0.56 \mathrm{l} \cdot \mathrm{tkm}^{-1}$ during the extracting of logs and $0.78 \mathrm{I} \cdot \mathrm{tkm}^{-1}$ during the extraction of energy wood. The results also show an increasing trend of fuel consumption expressed per ton of transported load with the increase of travelled distance during the extraction.

Conclusions: Fuel consumption expressed in $1 \cdot \mathrm{tkm}^{-1}$ is the most accurate fuel consumption indicator because it allows a realistic comparison of different types of machines with different loads $\left(t, \mathrm{~m}^{3}\right)$ at different extracting distances. The higher fuel consumption of an unloaded forwarder compared to a loaded forwarder can be explained with an increased wheel slip of an unloaded forwarder due to reduced traction between wheels and the soil both in the extraction of logs and energy wood.
\end{abstract}

Keywords: wood extraction, fleet management system, fuel flowmeter, even-aged forests, fuel consumption, energy wood

\section{INTRODUCTION}

Fuel consumption in timber harvesting operations is of economic (costs) and ecological (harmful exhaust gases) importance. Fuel consumption by volume of produced wood may vary depending on ground and operating conditions, driver skills, engine load under working conditions, engine speed, type and technical characteristics of the machine [1].

Determining the influence of certain factors is restricted by the interaction between individual factors. The influence of the machine on fuel consumption is reflected in the technical characteristics of the propulsion engine, the morphological characteristics of the machine, and the way the machine is maintained. The driver influences the fuel consumption by the way of driving, training and caring for the machine's operation [2].

Fuel consumption is mostly influenced by working conditions during timber harvesting operations, which usually include the slope of the terrain, extraction distance, load size and the variety of wood assortments [1].

Rational organisation of timber extraction operations consists of a series of factors that can affect the reduction of fuel consumption and thus the other costs of exploitation as well. 
The simplest way to measure fuel consumption of machinery and vehicles is the volumetric method of replenishing tank at the end of the work cycle, work operation or the end of the working day. The filling up of the tank is carried out by using a measuring gauge or by using a measuring gun for accurate measurements [2].

Nordfjell et al. [1] state that fuel consumption is traditionally measured by flowmeters [2-4], while new technologies, especially those based on CAN (Controller Area Network) bus technique, enable cheaper and easier measurements because every modern machine already has fuel measuring device as a part of the propulsion engine [5]. The CAN bus technique makes it easier to analyse fuel consumption at a certain moment, which is crucial when defining the most important factors of fuel consumption [6].

Fuel costs reach $10 \%$ of the total cost of machine felling and processing in CTL (Cut To Length) method in Canadian forestry [7], while Johansson [8] states that the share of fuel in total costs in Sweden reaches $20 \%$ since fuel prices are much higher than in North America. Fuel prices increased considerably at the beginning of this millennium, so at present fuel share in total costs is even higher [6].

Nordfjell et al. [1] estimate that fuel consumption of an unloaded forwarder is within the range of 0.23 to 0.38 litres per 100 meters, while fuel consumption of a loaded forwarder is $10 \%$ higher in comparison to the unloaded forwarder. According to the results of their research, they state that the average fuel consumption of a forwarder is $13.3 \mathrm{l} \cdot \mathrm{h}^{-1}$ when working in the final cut stand, or $10.5 \mathrm{l} \cdot \mathrm{h}^{-1}$ in the thinning stand.

Holzleitner et al. [9] present the research results of 18 forwarders (6 models) for the period from 2004 to 2008 in Austrian state forests where the average fuel consumption was $11.1 \mathrm{l} \cdot \mathrm{h}^{-1}$. Rieppo and Örn [5] report the average fuel consumption of $10.5 \mathrm{I} \cdot \mathrm{h}^{-1}$, while Nordfjell et al. [1] report that $61-62 \%$ of the fuel is consumed during loading and driving of a loaded forwarder. The results of both papers are based on the average values of a large number of researched forwarders in which detailed analyses of the influence of ground surface and fuel system on fuel consumption are neglected [6]. Đuka et al. [10] give calculated data on the energy consumption of forwarders according to Athanassiadis [11], who states that in Sweden the average estimated fuel consumption of forwarders is $0.935 \mathrm{I} \cdot \mathrm{m}^{-3}$ of roundwood without bark. Ackerman et al. [12] state that fuel consumption amounts to $0.38 \mathrm{l} \cdot \mathrm{m}^{-3}$ or $13.45 \mathrm{l} \cdot \mathrm{h}^{-1}$ when extracting wood assortments from pine stands in South Africa. Suvinen [6] states that steep terrain, and especially driving on uphill slopes when loaded, will naturally increase fuel consumption substantially.

Based on the results obtained by comprehensive field research, Nordfjell et al. [1] provide an equation for the calculation of fuel consumption of a 20 to 21-ton forwarder while extracting technical roundwood and pulpwood without bark in conditions of good soil bearing capacity:

$$
Q=0.288+(0.00638 / V) \cdot L
$$

where: $Q$ is fuel consumption $\left(1 \cdot \mathrm{m}^{-3}\right), \mathrm{V}$ is load volume $\left(\mathrm{m}^{3}\right)$, and $L$ is average extraction distance $(m)$.
Löfroth and Rådström [13] point to a reduction of forwarder's fuel consumption in primary timber transport in Sweden, where fuel consumption decreased from $2.5 \mathrm{I} \cdot \mathrm{m}^{-3}$ to $1.7 \mathrm{l} \cdot \mathrm{m}^{-3}$ between 1985 and 2005 . This reduction is attributed to the cooperation between machine manufacturers, users of these machines, and researchers. Machines and working methods of the increasing efficiency have quickly been introduced on a wide scale. As future guidelines for reducing fuel consumption, they introduce: the application of more efficient diesel engines, the increase in the efficiency of the hydraulic system whose efficiency is still under $60 \%$, the incorporation of the CTI (Central Tire Inflation) system, which has a beneficial effect on fuel consumption and soil damages, energy recovery from lowering individual hydraulic crane boom due to gravity, both optimization of export trails and marking of logs in the forest with the help of the GPS devices in order to avoid the search and, of course, further development and improvement of the electric-hybrid forwarder.

A forwarder with an electric-hybrid transmission, compared to the classic hydrostatic-mechanical transmission, has lower fuel consumption of 20 to $50 \%$. Such forwarder is also lighter because of a simpler transmission that does not have a bogie axle. Its mass is $9500 \mathrm{~kg}$, while its carrying capacity is $12,000 \mathrm{~kg}[14,15]$.

The aim of this research was to show the fuel consumption of a Valmet 840.2 forwarder in the extraction of logs and energy wood during seeding felling in a lowland stand of pedunculate oak, narrow-leafed ash and hornbeam.

\section{MATERIALS AND METHODS}

\section{Study Area}

The research was conducted in Forest Administration Vinkovci, Forest Office Otok, management unit Slavir, subcompartment 143a (N 4503'52.2", E 1853'35.4") during seeding felling in a 134 year-old stand of pedunculate oak, narrow-leafed ash and common hornbeam. The main characteristics of the researched forest stand are flat terrain, $79 \mathrm{~m}$ altitude, and average extraction distance $1125 \mathrm{~m}$. A total of 249 trees with the total volume of $536 \mathrm{~m}^{3}$ were assigned for felling.

In the researched department of 4.91 hectares, felling and processing were made with a chainsaw. Felling was directed to avoid overlapping and hitting the remaining trees. Forest residues were transported by a forwarder, which means that the extraction of energy wood took place after the extraction of logs. Felling and extracting were timeseparated. The timber was processed by a buck-to-quality method according to the valid norms, while the crowns were cut in a way to make the loading and transportation of energy wood easier. Average length of logs was $3.5 \mathrm{~m}$ ( $\min 2.0 \mathrm{~m}$, max $7.4 \mathrm{~m}$ ), average diameter $36 \mathrm{~cm}$ ( $\min 20$ $\mathrm{cm}, \max 66 \mathrm{~cm})$ and average volume $0.4 \mathrm{~m}^{3}\left(\min 0.1 \mathrm{~m}^{3}\right.$, $\max 1.6 \mathrm{~m}^{3}$ ). The main characteristic of energy wood loads is low density of the load which consists of crown branches of felled trees with a lot of air space between the branches. Energy wood loads are much longer than loads of logs, but because of low density, the average weight of energy wood 
load is approximately $30 \%$ lower than the average weight of a load of logs.

During the extraction of the logs, the ground was covered with a $10 \mathrm{~cm}$ thick snow that was melting with every day. The snow has completely melted until the last day of the extraction of energy wood.

The research object was a 6-wheel Valmet 840.2 forwarder shown in Figure 1, whose technical features are shown in Table 1.

For the purpose of measuring fuel consumption on the researched forwarder Valmet 840.2, a differential flow device was installed (Figure 2). This device was installed on the fuel supply line that supplies fuel from the fuel tank to the high-pressure fuel pump on the propulsion engine. Since the pump always supplies more fuel than the engine consumes, a certain amount of fuel is always returned to the tank. To measure the exact amount of used fuel, the return quantity also passes through the measuring device, so a differential correction was made.

The advantage of this measuring device is precise measurement of fuel consumption, and one of the disadvantages is its sensitivity to impurities that may appear in the fuel [16].

With newer engine types with built-in sensors, the installation of this meter may result in a drop in pressure in the fuel supply system, as well as in difficulties in the

TABLE 1. Main technical characteristics of Valmet 840.2 forwarder.

\begin{tabular}{|c|c|}
\hline \multicolumn{2}{|c|}{ Valmet 840.2} \\
\hline Drive equation & $6 \times 6$ \\
\hline Mass (kg) - declared/weighted* & $13,800 / 16,100$ \\
\hline Load carrying capacity (kg) & 11,000 \\
\hline Length (mm) & 9007 \\
\hline Width (mm) & 2640 \\
\hline Height (mm) & 3800 \\
\hline Ground clearance (mm) & 680 \\
\hline Engine type & Valmet 620 DWRE \\
\hline Power (kW) at $2200 \mathrm{rpm}$ & 124 \\
\hline Euro emission standard & Euro 2 \\
\hline Torque (Nm) & $670 \mathrm{Nm}$ at $1400 \mathrm{rpm}$ \\
\hline Transmission & Hydrostatic-mechanical \\
\hline Length of bunk area (mm) & 4200 \\
\hline Hydraulic crane type & CRF 7 \\
\hline Maximum crane reach $(\mathrm{m})$ & 9.1 \\
\hline Tires: front & $600 / 65 \times 34$ \\
\hline Tires: rear & $600 / 55 \times 26.5$ \\
\hline
\end{tabular}

*Declared - listed in the prospectus for the basic model; , weighted a real mass of the researched forwarder with additional equipment (bigger/stronger hydraulic crane, front pushing board, etc.) propulsion engine operation. Instead of this type of meter, for fuel consumption measurement, a metering probe installed in the fuel tank can be used. The main disadvantage of the measuring probe is lower precision than with the differential fuel consumption meter.

FMS (Fleet Management System) was used for data transfer. Its role is to record specific parameters on the vehicle and wirelessly send the recorded data via GPRS or SMS through the monitoring centre to the end user. The end user has insight into vehicle parameters by connecting to the internet using a computer or a mobile phone. The standard parameters that are monitored on almost every vehicle are the current position of the vehicle, fuel consumption, engine speed, etc. The basic component of the FMS is a mobile unit

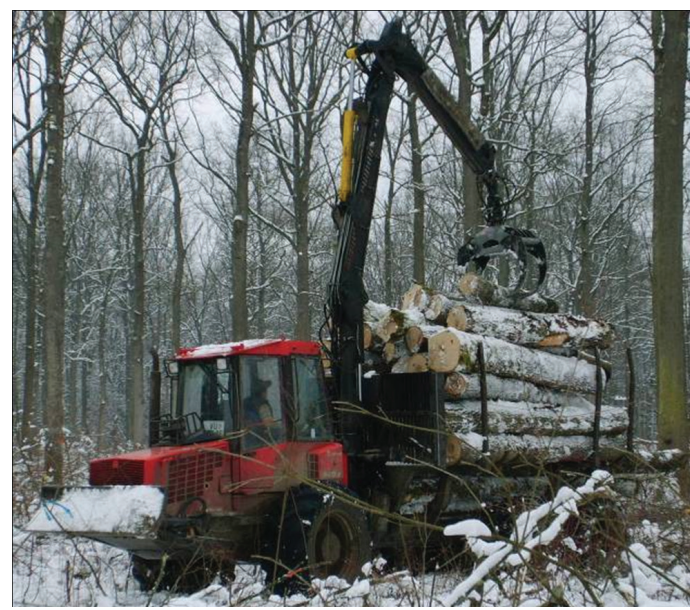

FIGURE 1. Valmet 840.2 forwarder.

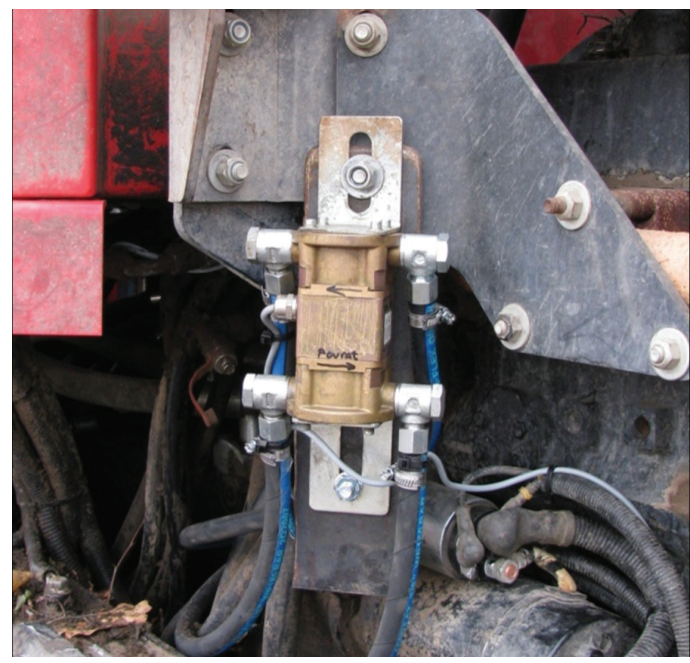

FIGURE 2. Differential fuel EltraTec flowmeter and its technical characteristics (Type: EltraTec - FFS/l; Power supply: 10-30 V; Electricity consumption: $40 \mathrm{~mA}$; Accuracy: $\pm 3 \%$; Protection: IP 65 ; Minimum fuel flow: 67 $\mathrm{ml} \cdot \mathrm{min}^{-1}$; Maximum fuel flow: $3.3 \mathrm{l} \cdot \mathrm{min}^{-1}$ ). 
that is installed in the vehicle and at any time that allows position monitoring via a GPS device (navigation component) which is its integral part. For vehicle communication with the control centre, the mobile unit also has a built-in GPRS modem that represents the communication component. The biggest advantage of the mobile unit is that it can be connected to different measuring transducers which can be used to monitor the operation of the machine. The measuring transducers that were connected to the mobile unit in this study were a flowmeter for measuring fuel consumption and a tachometer for measuring the speed of the propulsion engine. The mobile unit was also connected to forwarder's computer and to one of the solenoid valves of the hydraulic installation through which the hydraulic crane is operated.

\section{Research Methods}

In the data obtained from the control centre system, containing the fuel consumption along with the coordinates of the forwarder's position, detection of hydraulic crane operation and the engine speed is shown in dependency of time. By comparing all recorded parameters using the ArcGIS program package the transition (fix) points that represent the transition between individual components of the cycle were determined. Each cycle is divided into four basic components: driving unloaded, loading, driving loaded and unloading. Based on the transition points, fuel consumption was calculated for each of the individual cycle components and finally the total fuel consumption was calculated for each cycle $\left(1 \cdot\right.$ cycle $\left.^{-1}\right)$.

With the help of the transition points, through calculation, time duration of each of the components of the extraction was obtained, which provided data for the calculation of the total duration of each cycle and hourly fuel consumption $\left(I \cdot h^{-1}\right)$.

Using ArcGIS program package, based on the recorded coordinates of the position of the forwarder, the length of the travelled distance was obtained and the fuel consumption was expressed by consumed fuel per $100 \mathrm{~m}$ of the travelled distance $\left(1 \cdot 100 \mathrm{~m}^{-1}\right)$.

During the extraction of logs, the numbers on identification plates of the assortments were noted down on the landing site. Identification plates were put on the front of every log in the forest stand after processing and before extraction. Based on these numbers gross volume (with bark) of each piece of roundwood in each cycle of the forwarder was obtained. The length of the logs was measured with the measuring tape and the mean diameter in the centre of the log with the calliper. Fuel consumption in each cycle of the forwarder was related to the total gross volume of logs, and on this basis, fuel consumption per cubic meter of extracted timber $\left(1 \cdot \mathrm{m}^{-3}\right)$ was obtained.

During the departure of the forwarder from the stand to the forest road, which is also a landing site, a portable measuring platform which is described by Bosner et al. [17] for measuring the axle load of the forwarder was installed on stable and flat terrain next to the forest road and near the landing site. For each cycle, the measuring platform was used during the extraction of logs and energy wood. By measuring axle load of an empty and a full forwarder, the mass of the load in each cycle was obtained. With the ratio of the consumed fuel to the load mass in each cycle, fuel consumption per ton of extracted wood $\left(1 \cdot \mathrm{t}^{-1}\right)$ was obtained.

The most accurate way to express fuel consumption is through the ratio of consumed fuel to the travelled distance and to the mass of the extracted wood $\left(1 \cdot \mathrm{tkm}^{-1}\right)$, because consumption is expressed in such a way that it can be compared to other vehicles, regardless of the working conditions. Fuel consumption expressed in $1 . \mathrm{tkm}^{-1}$ allows a realistic comparison of different types of machines with different loads $\left(\mathrm{t}, \mathrm{m}^{3}\right)$ at different extracting distances.

Statistical analysis was carried out in the StatSoft STATISTICA 8 software package. To make conclusions about the significance of the difference between the two independent data sets, the Student's t-test was used with a level of $5 \%$ significance $(p<0.05)$. In the study of stochastic dependence between satisfying correlated variables, regression analysis was used. The selection of the equalisation curve was carried out by the coefficient of the correlation ( $\mathrm{R})$, $t$-variable (t-Stat), the probability value ( $p$-value) and regression coefficients.

\section{RESULTS}

The fuel consumption of the Valmet 840.2 forwarder was measured during the transport of forest residues and while extracting logs and energy wood from subcompartment 143a (management unit Slavir) during seeding felling in the stand of pedunculate oak, narrow-leafed ash and hornbeam (Figure 3).

Table 2 shows the average values of fuel consumption for 28 cycles of extracting logs and 24 cycles of extracting energy wood. The fuel consumption is expressed in six different ways concerning: cycle, extraction distance of 100 $\mathrm{m}$, time (hour), load mass (tons), gross load volume $\left(\mathrm{m}^{3}\right)$ and product of mass, and transporting distance (tkm).

TABLE 2. Fuel consumption of a Valmet 840.2 forwarder.

\begin{tabular}{|c|c|c|c|c|c|c|c|c|c|c|}
\hline & \multirow{2}{*}{ Cycles-N } & \multirow{2}{*}{$\frac{\text { Load mass }}{\mathrm{kg}}$} & \multirow{2}{*}{$\begin{array}{c}\begin{array}{c}\text { Load } \\
\text { volume }\end{array} \\
\mathrm{m}^{3}\end{array}$} & \multirow{2}{*}{$\begin{array}{c}\begin{array}{c}\text { Total travelled } \\
\text { distance }\end{array} \\
\mathrm{m}\end{array}$} & \multicolumn{6}{|c|}{ Fuel consumption - $Q$} \\
\hline & & & & & |. cycle $^{-1}$ & $\mathrm{I} \cdot 100 \mathrm{~m}^{-1}$ & $\mid \cdot h^{-1}$ & $\mid \cdot t^{-1}$ & $1 \cdot m^{3}$ & I.tkm \\
\hline Logs & 28 & $12317^{a}$ & 13.37 & $2272^{\mathrm{a}}$ & $15.61^{\mathrm{a}}$ & $0.69^{a}$ & $17.36^{\mathrm{a}}$ & $1.29^{\mathrm{a}}$ & 1.18 & $0.56^{\mathrm{a}}$ \\
\hline En. wood & 24 & $8468^{b}$ & & $2235^{a}$ & $14.81^{\mathrm{a}}$ & $0.66^{\mathrm{a}}$ & $15.17^{b}$ & $1.74^{b}$ & & $0.78^{b}$ \\
\hline
\end{tabular}

\footnotetext{
${ }^{\text {a b }}$ values in the same column marked with the same letter do not represent statistically significant difference according to $t-$ test $(p<0.05)$
} 


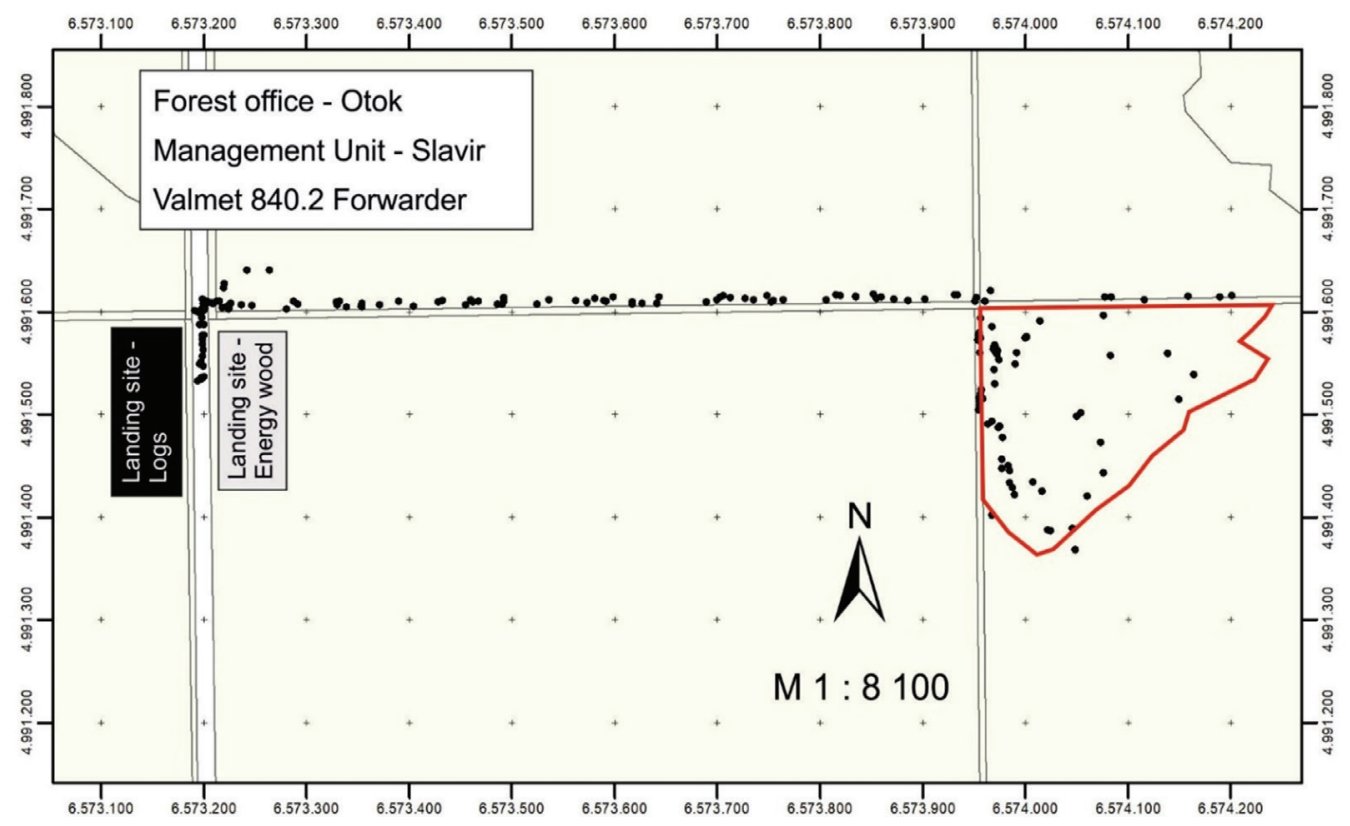

FIGURE 3. Sub-compartment 143a with positions of landing sites for roundwood, long-meter firewood and energy wood.

In the case of fuel consumption per cycle, higher consumption was measured during the extraction of logs $\left(15.61 \mathrm{l} \cdot \mathrm{cycle}^{-1}\right)$ than when extracting energy wood $(14.81$ I.cycle $\left.{ }^{-1}\right)$, but according to statistical analysis using t-test, there is no significant difference in consumption per cycle between these two variants with a probability of $95 \%$.

Regarding fuel consumption per distance of $100 \mathrm{~m}$, there is no significant difference between the consumption during the extraction of logs and energy wood, but consumption is also higher during the extraction of logs $\left(0.69 \mathrm{l} \cdot 100 \mathrm{~m}^{-1}\right)$ than during the extraction of energy wood $\left(0.66 \mathrm{l} \cdot 100 \mathrm{~m}^{-1}\right)$.

Calculated hourly fuel consumption is higher while extracting logs $\left(17.36 \mathrm{l} \cdot \mathrm{h}^{-1}\right)$ and statistically differs from hourly consumption while extracting energy wood (15.17 I. $\left.h^{-1}\right)$.

The reason for higher fuel consumption while extracting logs can be attributed to the higher mass (and also the density) of the load, which averaged in 12,317 kg and which is statistically different from the average mass of energy wood (8468 kg), since the extraction distance for logs (2272 $\mathrm{m}$ ) and energy wood ( $2335 \mathrm{~m}$ ) is not statistically different.

Fuel consumption per metric tons of transported load is higher when extracting energy wood $\left(1.74 \mathrm{I}^{-1} \mathrm{t}^{-1}\right)$ and statistically differs from fuel consumption when extracting logs $\left(1.29 \mathrm{l} \cdot \mathrm{t}^{-1}\right)$. The reason for the higher fuel consumption during the extraction of energy wood expressed in this way is the lower average mass of energy wood load as compared to the load mass of logs.

Fuel consumption per gross volume of the load when extracting roundwood is $1.18 \mathrm{I} \cdot \mathrm{m}^{-3}$. According to the fuel consumption expressed in $\mathrm{I} \cdot \mathrm{tkm}^{-1}$, the value of $0.56 \mathrm{l} \cdot \mathrm{tkm}^{-1}$ was achieved while extracting logs from sub-compartment 143a, while fuel consumption during the extraction of energy wood from the same sub-compartment was 0.78 $\mathrm{l} \cdot \mathrm{tkm}^{-1}$. These two values statistically differ.

The diagrams in Figure 4 show an increasing trend of fuel consumption expressed per ton of transported load with the increase of travelled distance during the extraction of logs (Figure 4a) and energy wood (Figure 4b). The increasing trend is the same while extracting both the logs and energy wood, but the amount of fuel consumption is higher when it comes to energy wood extraction because of the reduced load mass. Due to large dispersion of fuel consumption data expressed per tons of transported load, low coefficients of determination were obtained (in the case of extracting the logs $R^{2}=0.13$ and of extracting energy wood $\left.R^{2}=0.06\right)$. As expected, there is no dependence between fuel consumption and extraction distance.

According to Table 3, the biggest share in forwarders' fuel consumption is when driving unloaded. In both of the stated components the share of spent time is the same (driving unloaded: logs $-16.8 \%$ and energy wood - 17.8\%; driving loaded: logs - $19.5 \%$ and energy wood - 20.9\%), so the share of fuel consumption in these components is similar. The shares of travelled distance in the mentioned components are similar as well. Together they make over $80 \%$ of the total travelled distance of an average cycle. In this case, the travelled distance has a greater impact on the total fuel consumption than the time duration of the components of wood extraction cycle.

In the case of a loading component, the share of fuel consumption while loading energy wood (27.2\%) was higher than while loading logs (17.2\%). While loading energy wood, the share of time spent is also higher $(42.3 \%)$ as compared 

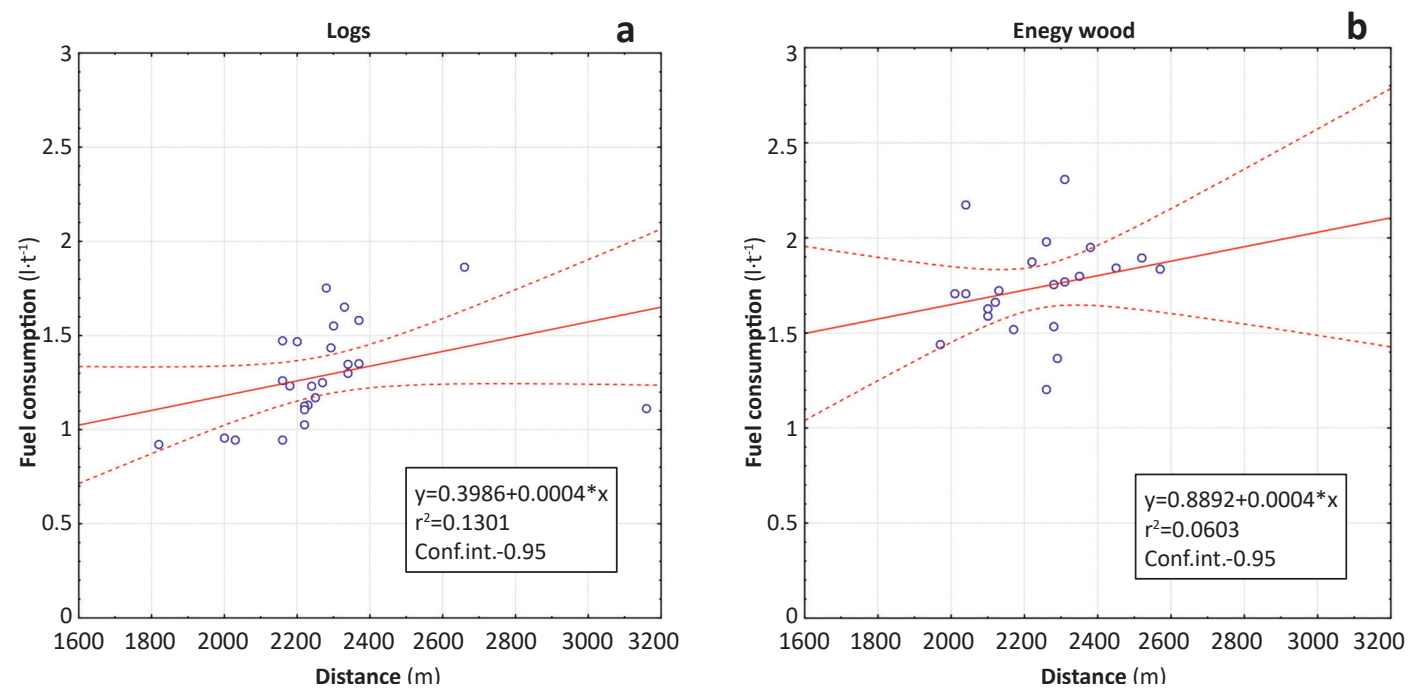

FIGURE 4. Dependence of fuel consumption per load mass on the total driving distance.

TABLE 3. The shares of fuel consumption by components of the working cycle.

\begin{tabular}{|c|c|c|c|c|c|c|c|c|}
\hline & \multicolumn{2}{|c|}{ Share of time (\%) } & \multicolumn{2}{|c|}{$\begin{array}{c}\text { Share of fuel consumption } \\
(\%)\end{array}$} & \multicolumn{2}{|c|}{ Share of driven distance (\%) } & \multicolumn{2}{|c|}{$\begin{array}{c}\mathrm{N} \text { hydraulic crane } \\
\text { engagement }\end{array}$} \\
\hline & Logs & En. wood & Logs & En. wood & Logs & En. wood & Logs & En. wood \\
\hline Driving - unloaded & 16.8 & 17.8 & 30.2 & 32.3 & 41.2 & 42.5 & & \\
\hline Loading & 29.0 & 42.3 & 17.2 & 27.2 & 7.7 & 9.8 & 99 & 163 \\
\hline Driving - loaded & 19.5 & 20.9 & 28.2 & 28.2 & 42.5 & 44.4 & & \\
\hline Unloading & 34.7 & 19.0 & 24.4 & 12.3 & 8.6 & 3.4 & 163 & 78 \\
\hline
\end{tabular}

to time spent while loading logs (29\%). The reason for the higher fuel consumption and the amount of time spent when loading energy wood is the higher number of electrovalve engagements for the displacement of the hydraulic crane (163) or the higher workload of the hydraulic crane as compared to loading logs where on average 99 engagements were detected. The reason for the increased number of hydraulic crane engagements while unloading logs is of an organizational nature. Logs were subsequently measured at the landing site in order to control the measurements previously done in the stand. Thus, it can be assumed that the number of hydraulic crane engagements (163) was in fact three times higher than it would be in normal working circumstances, which would amount to around 55 engagements. In that case, the workload of the hydraulic crane would be lower both while loading and unloading logs as compared to loading and unloading energy wood.

\section{DISCUSSION WITH CONCLUSIONS}

The reasons for the increased fuel consumption of the researched forwarder, compared to the results of previous studies, are unfavourable conditions during extraction (snow melting) (Figure 5) which led to increased wheel slip (15.81\% - measured in the stand), and a large share of driving on wet trails (during extraction of logs and energy wood $74 \%$ and $75.6 \%$ respectively of the total travelled distance on a trail). The higher fuel consumption of an unloaded forwarder as compared to a loaded forwarder (Table 3 ) can be explained with an increased wheel slip of an unloaded forwarder due to a reduced traction between wheels and the soil in both the extraction of logs and energy wood.

According to Nordfjell et al. [1], the parameters of calculation are based on the load volume in cubic meters and the average extraction distance in meters. The calculated fuel consumption of the investigated forwarder was 0.77 $\mathrm{l} \cdot \mathrm{m}^{-3}$, while the measured consumption was $1.18 \mathrm{I} \cdot \mathrm{m}^{-3}$. The reason for such significant deviation is due to the greater average extraction distance $(1136 \mathrm{~m})$, while Nordfjell et al. [1] conclude that the term is suitable for an average extraction distance of about $400 \mathrm{~m}$.

The diagrams in Figure 6 show an increasing trend of fuel consumption expressed per ton of transported load with the increase of travelled distance and the decrease of productivity during the extraction of logs (Figure 6a) and 
energy wood (Figure 6b). The increasing trend is the same while extracting both the logs and energy wood, but the amount of fuel consumption is higher when it comes to energy wood extraction because of the reduced productivity. Lower productivity is a consequence of the reduced load mass during energy wood extraction. Equations of fuel consumption dependence per load mass on the total driving distance and productivity are noted in diagrams in Figure 6a for extracting logs and Figure $6 \mathrm{~b}$ for extracting energy wood.

Fuel consumption expressed in $1 \cdot \mathrm{tkm}^{-1}$ is the most accurate fuel consumption indicator because it allows a realistic comparison of different types of machines with different loads $\left(t, \mathrm{~m}^{3}\right)$ at different extracting distances. This claim has been confirmed by the results of this research.

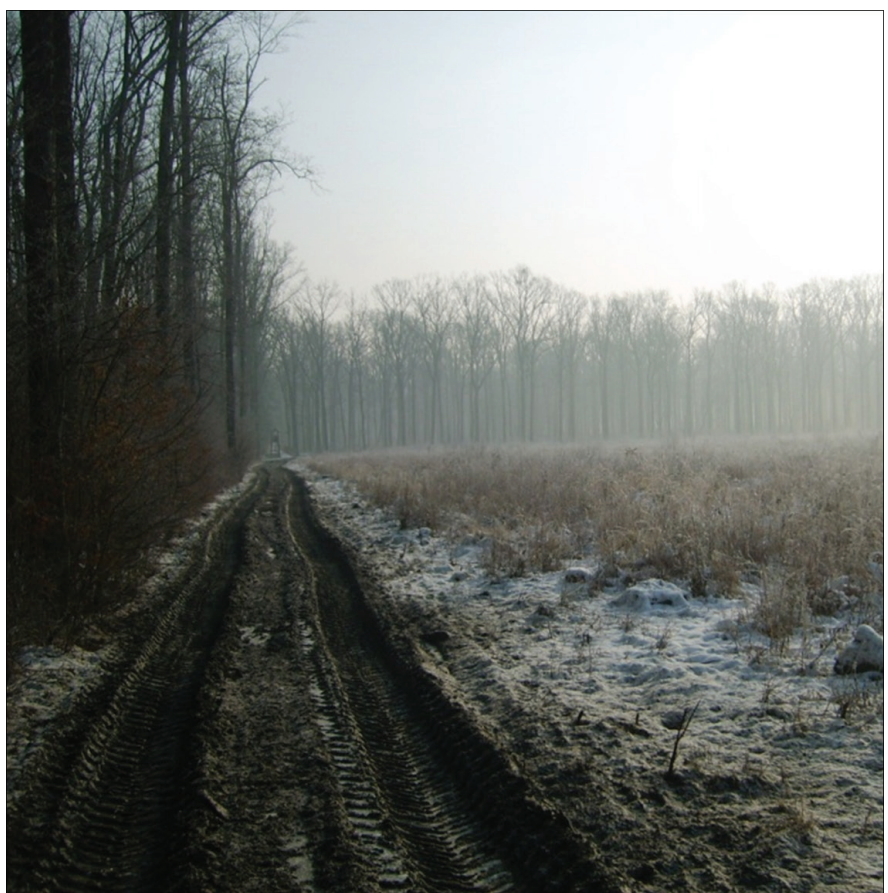

FIGURE 5. The state of the trail during extraction with the Valmet 840.2 forwarder.

Logs

$Q-0.0002 * \mid-0.0504 * P+1.5248$

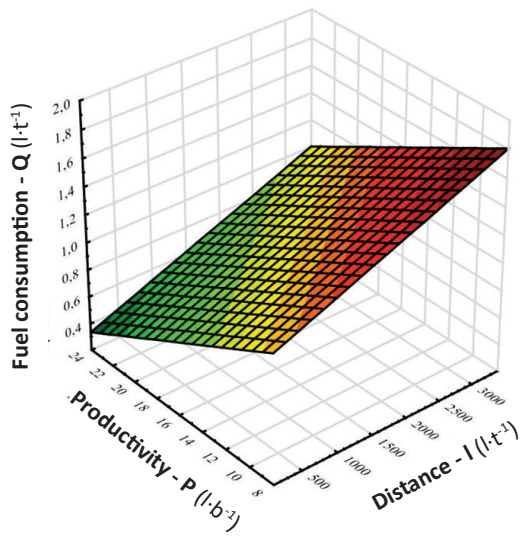

a

Enegy wood

Q $-0.0001 * \mid-0.149 * P+2.8168$

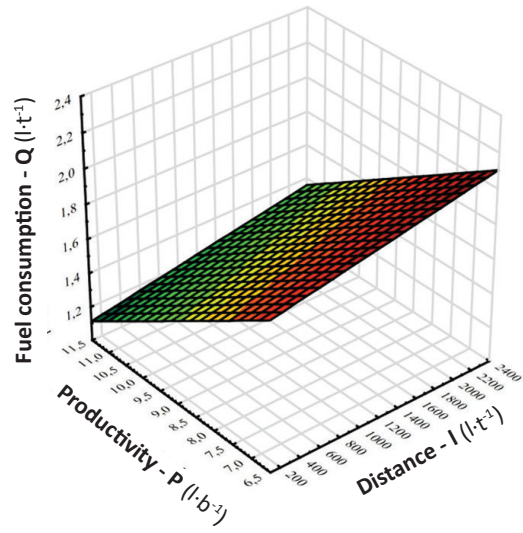

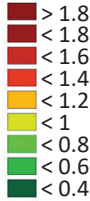

FIGURE 6. Dependence of fuel consumption per load mass on the total driving distance and productivity. 


\section{REFERENCES}

1. NORDFJELL T, ATHANASSIADIS D, TALBOT B 2003 Fuel consumption in forwarders. Int J Forest Eng 14 (2): 11-20

2. SEVER S, HORVAT D 1989 Prilog proučavanja potrošnje goriva pri prijevozu drva kamionskim kompozicijama. Mehanizacija šumarstva 14 (7-8): 157-162

3. REBULA E 1989 Potrošnja goriva pri privlačenju drva $s$ traktorima IMT 560 i IMT 567. Mehanizacija šumarstva 14 (7-8): 151-155

4. POTOČNIK I 1989 Potrošnja goriva kamiona Magirus pri prijevozu drva. Mehanizacija šumarstva 14 (7-8): 145-156

5. RIEPPO K, ÖRN J 2003 Measuring the fuel consumption of forest machines Metsätehon raportti 148, 19 May2003, Esitutkimus.

6. SUVINEN A 2006 Economic Comparison of the Use of Tyres, Wheel Chains and Bogie Tracks for Timber Extraction. Croat J Forest Eng 27 (2): 81-102

7. FAVREAU J, GINGRAS JF 1998 An analysis of harvesting costs in eastern Canada. Forest Engineering Research Institute of Canada, Special Report SR-129

8. JOHANSSON A 2001 Forestry Costs and Revenues 2000, A year of storms and floods. Forestry Research Institute of Sweden, Results nr. 4, Uppsala, Sweden.

9. HOLZLEITNER F, STAMPFER K, GHAFFARIYAN MR, VISSER R 2010 Economic benefits of long term forestry machine data capture: Austrian Federal Forest case study. In: Formec 2010, Forest Engineering: Meeting the Needs of the Society and the Environment, 11-14 July 2010, Padova, Italy, $8 \mathrm{p}$.
10. ĐUKA A, VUSIĆ D, HORVAT D, ŠUŠNJAR M, PANDUR Z, PAPA I 2017 LCA studies in forestry - Stagnation or progress. Croat J Forest Eng 38 (2): 311-326

11. ATHANASSIADIS D 2000 Energy consumption and exhaust emissions in mechanised timber harvesting operations in Sweden. Sci Total Environ 255 (1-3): 137-145. DOI: https:// doi.org/10.1016/S0048-9697(00)00463-0

12. ACKERMAN P, WILLIAMS C, ACKERMAN S, NATI C 2017 Diesel consumption and carbon balance in South African pine clear-felling CTL Operations: a preliminary case study. Croat J Forest Eng 38 (1): 65-72

13. LÖFROTH C, RÅDSTRÖM L 2006 Fuel consumption in forestry continues to fall. Results from Skogforsk No. 3

14. LÖFROTH C, JÖNSSON P, NORDÉN B, HOFSTEN H 2007 Hybrid forwarder achieves considerable reduction in fuel consumption. Results from Skogforsk No. 3

15. SPINELLI R 2011 Supply of wood biomass for energy purpose: global trends and perspectives. In: $22^{\text {nd }}$ Annual Meeting of the Club of Bologna, Hannover, Germany

16. PANDUR Z, HORVAT D, ŠUŠNJAR M, ŠARAC Z 2009 Može li se komercijalni Fleet Management Sustav koristiti u praćenju rada i istraživanjima forvardera? Nova mehanizacija šumarstva 30 (1): 11-17

17. BOSNER A, NIKOLIĆ S, PANDUR Z, BENIĆ D 2008 Razvoj i umjeravanje prijenosnoga sustava za mjerenje osovinskih opterećenja vozila - mjerenja na forvarderu. Nova mehanizacija šumarstva 29 (1): 1-15 